\title{
HUBUNGAN KADAR HORMON OKSITOSIN TERHADAP LAMA KALA III PERSALINAN SERTA PENGARUHNYA TERHADAP JUMLAH PERDARAHAN PADA IBU 2 JAM POSTPARTUM
}

\author{
Desi Sarli' ${ }^{1}$, \\ ${ }^{1}$ Akademi Kebidanan Alifah Padang \\ email: desi_sarli@yahoo.com
}

\begin{abstract}
ABSTRAK
Angka Kematian Ibu (AKI) akibat persalinan sampai saat ini masih merupakan salah satu masalah kesehatan dunia. Perdarahan yang disebabkan oleh atonia uteri merupakan penyebab kematian ibu bersalin yang memberikan kontribusi paling besar $(25 \%)$ terhadap seluruh penyebab kematian ibu melahirkan. Manajemen aktif kala III yang salah satunya adalah pemberian oksitosin merupakan tindakan untuk mempercepat persalinan kala III dan mencegah terjadinya perdarahan. Tujuan penelitian ini adalah untuk mengetahui hubungan kadar hormon oksitosin terhadap lama kala III persalinan, untuk mengetahui hubungan kadar hormone oksitosin terhadap jumlah perdarahan, untuk mengetahui hubungan lama kala III dengan jumlah perdarahan postpartum. Penelitian ini menggunakan observasi dengan desain penelitian crosssectional, penelitian ini dilaksanakan \pm 6 bulan. Sasaran penelitian ini adalah ibu yang bersalin normal dengan 30 responden. Pengukuran waktu lama kala III akan dicatat dimulai setelah bayi lahir dan untuk menilai jumlah perdarahan kala IV peneliti melakukan penimbangan underpad kemudian dianalisa dengan rumus volume $(\mathrm{ml})=$ berat/massa jenis darah $(1,056)$. Pemeriksaan kadar oksitosin dilakukan menggunakan Human Oxytocin Elisa Kit. Analisis data dilakukan secara univariat dan bivariat menggunakan uji statistik korelasi dan regresi $(p<0,05)$ dengan komputerisasi. Hasil penelitian yang telah dilakukan pada 30 orang ibu bersalin menunjukkan bahwa rata-rata kadar hormon oksitosin sebesar 50,41 $\pm 2,07 \mathrm{pg} / \mathrm{ml}$, rata - rata lama kala III 5,7 menit $\pm 1,89$ menit dan rata - rata jumlah perdarahan postpartum $157,15 \pm 76,51 \mathrm{ml}$. Setelah dilakukan uji sttatistik terdapat hubungan yang kuat antara kadar hormon oksitosin terhadap lama kala III ( $\mathrm{r}=0,702$ dan $\mathrm{p}=0,0001)$, terdapat hubungan dengan kategori sedang antara kadar hormon oksitosin dengan jumlah perdarahan postpartum $(\mathrm{r}=0,514$ dan $\mathrm{P}=0,004)$. Terdapat hubungan dengan kategori sedang antara lama kala III dengan jumlah perdarahan postpartum ( $\mathrm{r}=0,575$ dan $\mathrm{P}=0,001)$. Berdasarkan hasil tersebut dapat disimpulkan bahwa semakin tinggi kadar oksitosin maka semakin sedikit waktu lama kala III, semakin tinggi kadar oksitosin semakin sedikit jumlah perdarahan postpartum, dan semakin sedikit waktu lama kala III maka semakin sedikit jumlah perdarahan postpartum.
\end{abstract}

Kata kunci : Oksitosin, Lama Kala III, Jumlah Perdarahan

ABSTRACT

Maternal Mortality Rate due to childbirth is still one of the world's health problems. Bleeding caused by uterine atony is the leading cause of maternal death giving the greatest contribution (25\%) to all causes of maternal mortality. Active management of the third stage, one of which is the action of oxytocin is an action to accelerate the third stage of labor and prevention of bleeding flood. The aim of this research is to know the correlation of hormone oxytocin level on the time of the third stage of labor, to know the correlation of hormone oxytocin level to the amount of bleeding, to know the relation of the old time of III with the number of postpartum hemorrhage. This research use observation with crosssectional research design, this research is conducted \pm 6 month. The target of this research is normal maternal mother with 30 respondents. Measurements of the old time of the third stage will begin after birth and to assess the number of hemorrhage while IV underpad weighing is then analyzed by the volume formula $(\mathrm{ml})=$ weight / density of the blood type (1.056). Examination of oxytocin levels was performed using the Human Oxytocin Elisa Kit. Data were analyzed by univariate and bivariate using statistic and regression test $(p<0,05)$ with computerization. The result of the research that has been done on 30 maternal mothers showed the average of the hormone oxytocin level of 50,41 $\pm 2.07 \mathrm{pg} / \mathrm{ml}$, the mean time duration of III 5.7 minutes \pm 1.89 minutes and the average amount of bleeding postpartum 157,15 $\pm 76,51 \mathrm{ml}$ After the sttatistic test there was a strong correlation between the oxytocin hormone level on the time of the third stage $(r=0.702$ and $p=0.0001)$, there was a correlation with the moderate category between the oxytocin hormone levels and the amount of postpartum hemorrhage $(r=0,514$ and $P=0,004)$. There was a correlation with the moderate category between the time of the third stage with the number of postpartum hemorrhages $(r=0.575$ and $P=0.001)$. Based on these results it can be concluded that the higher the oxytocin level, the less time duration of the third stage, the higher the oxytocin level a little more the number of postpartum hemorrhage, and the less time of the third stage, the less the number of postpartum hemorrhages.

Keywords: Oxytocin, Old Kala III, Number of Bleeding 


\section{PENDAHULUAN}

Menurut World Health Organization (WHO) pada tahun 2010, sebanyak 536.000 perempuan meninggal akibat persalinan. Sebanyak $99 \%$ kematian ibu masalah persalinan atau kelahiran terjadi di negara-negara berkembang. Rasio kematian ibu di negara-negara berkembang merupakan tertinggi dengan 450 kematian ibu per 100.000 kelahiran bayi hidup jika dibandingkan dengan rasio kematian ibu di 9 negara maju dan 51 negara berkembang.

Berdasarkan Survei Demografi dan Kesehatan Indonesia (SDKI) 2012 didapatkan data Angka Kematian Ibu (AKI) 359 per 100.000 kelahiran hidup (KH) mengalami kenaikan yang signifikan jika dibandingkan dengan data AKI tahun 2007 yaitu sebesar 228 per $100.000 \mathrm{KH}$. Hasil ini sangat jauh dari target MDGs yaitu 102 per $100.000 \mathrm{KH}$. Sedangkan untuk data Angka Kematian Bayi (AKB) di Indonesia walaupun masih jauh dari angka target MDGs yaitu AKB tahun 2015 sebesar 23 per 1000 kelahiran hidup, tetapi tercatat mengalami penurunan yaitu pada tahun 2002 dari 35 per 1000 kelahiran hidup menjadi sebesar 34 per 1000 kelahiran hidup pada tahun 2007, dan terakhir menjadi 32 per 1000 kelahiran hidup (SDKI, 2012).

Secara global $80 \%$ kematian ibu tergolong pada kematian ibu langsung. Pola penyebab langsung kematian ibu yaitu perdarahan (25\%), biasanya perdarahan pasca persalinan), sepsis (15\%), hipertensi dalam kehamilan (12\%), partus macet (8\%), komplikasi aborsi tidak aman (13\%), dan sebab-sebab lain (8\%) (Prawirohardjo, 2010).

Frekuensi perdarahan postpartum berdasarkan laporan-laporan baik di negara maju maupun di negara berkembang angka kejadian berkisar antara $5 \%$ sampai $15 \%$. Dari angka tersebut, diperoleh gambaran etiologi antara lain: atonia uteri (50-60\%), sisa plasenta (23-24\%), retensio plasenta (16-17\%), laserasi jalan lahir (4-5\%), kelainan darah $(0,5-0,8 \%)$ (Norma, 2013).

Pelepasan plasenta lebih lama akan menyebabkan perdarahan postpartum sehingga itu yang dikhawatirkan oleh tenaga kesehatan. Sebagian plasenta (satu atau lebih lobus) tertinggal, maka uterus tidak dapat berkontraksi secara efektif dan keadaan ini dapat menimbulkan perdarahan (Prawirohardjo, 2010).

Menurut penelitian yang dilakukan oleh Magan pada tahun $2005 \mathrm{di}$ American College of Obstetricians dan Gynecologists dari $6.588 \mathrm{ibu}$ bersalin terdapat $355(5,1 \%)$ ibu yang mengalami perdarahan postpartum dengan lama kala III rata-rata lebih dari 18 menit. Lama kala III persalinan yang lebih dari 18 menit akan beresiko untuk terjadinya perdarahan postpartum. Sedangkan kala III yang lamanya lebih dari 30 menit kemungkinan akan mengalami perdarahan postpartum 6 kali lebih tinggi dari lama kala III yang kurang dari 30 menit (Magann, 2005)

Salah satu upaya untuk mempercepat waktu kala III adalah dengan pemberian oksitosin. Menurut penelitian Stanton, et al., (2013), menyatakan upaya penanganan perdarahan postpartum adalah dengan pemberian oksitosin, dimana oksitosin mempunyai peranan penting dalam merangsang kontraksi otot polos uterus sehingga perdarahan dapat teratasi. Hasil dari penelitiannya menunjukkan rata-rata jumlah perdarahan setelah plasenta lahir diberikan injeksi oksitosin lebih sedikit dibandingkan tanpa diberikan injeksi oksitosin.

Menurut penelitian Thornton, et al., (2004), menjelaskan bahwa oksitosin dapat dihasilkan oleh tubuh pada saat proses persalinan. Kadar oksitosin akan meningkat pada kala III oleh karena pengurangan metabolisme secara tiba-tiba karena pelepasan plasenta, dimana plasenta merupakan sumber utama oksitosin. Akibat pelepasan plasenta hipotalamus terstimulasi untuk menghasilkan hormon oksitosin.

Oleh sebab itu peneliti tertarik untuk membuktikan apakah ada hubungan kadar hormon oksitosin terhadap lama kala III persalinan serta pengaruhnya terhadap jumlah perdarahan postpartum.

Menurut penelitian Stanton, et al., (2013) Perdarahan merupakan penyebab utama kematian ibu di Negara miskin, diperkirakan sepertiga kejadian perdarahan ini bertanggung jawab atas kematian ibu setiap tahunnya. Perdarahan postpartum (PPH) umumnya disebabkan oleh atonia uteri. Kematian ibu yang disebabkan oleh perdarahan di bagian Sahara Afrika sebesar satu dari lima seluruh kematian ibu di seluruh dunia.

Pedoman WHO terbaru tentang pencegahan PPH merekomendasikan penggunaan obat uterotonika tanpa komponen lainnya, manajemen aktif kala III persalinan, dengan bidan terlatih. Sampai saat ini, WHO terus merekomendasikan oksitosin sebagai obat pilihan untuk pencegahan PPH pada persalinan rumah dan di fasilitas kesehatan karena efektivitas dan kurangnya efek samping (Thornton, et al., 2004).

Hasil dari data penelitian Stanton, et al., (2013) rata-rata jumlah perdarahan setelah plasenta lahir diberikan injeksi oksitosin adalah sebesar $185.5 \mathrm{ml}$ dan rata-rata jumlah perdarahan setelah plasenta lahir tanpa diberikan injeksi oksitosin $229.5 \mathrm{ml}$ (Stanton, et al., 2013).

Mekanisme kerja Oksitosin untuk mencegah perdarahan pada uterus adalah oksitosin berbentuk asam amnio peptida sembilan yang disintesa pada syaraf hipotalamus dan dialirkan ke akson dari pituitary posterior untuk disekresikan ke dalam darah. Oksitosin juga disekresikan ke dalam otak dan dari beberapa jaringan. Adapun fungsi dari oksitosin 
adalah menstimulasi kontraksi otot uterus untuk mencegah perdarahan (Stanton, et al., 2013).

Menurut penelitian Thornton, et al., (2004) menjelaskan bahwa 10 wanita yang diberikan oksitosin pada saat kelahiran plasenta menunjukkan peningkatan konsentrasi plasma oksitosin. Kadar oksitosin pada saat kelahiran janin (Kala II) adalah sebesar 3,9 pmol/1 kemudian meningkat pada saat kelahiran plasenta (Kala III) menjadi $23 \mathrm{pmol} / \mathrm{l}$ setelah pemberian oksitosin. Peneliti juga menjelaskan bahwa dari 15 wanita yang tidak diberikan oksitosin, 9 orang memiliki waktu kelahiran plasenta yang normal dan 4 orang lagi tidak, namun plasenta dapat lahir walau dengan waktu yang lebih lama dan 2 orang yang mengalami perdarahan postpartum akibat manual plasenta. Plasma oksitosin meningkat setelah Kala II dengan kadar oksitosin sebesar 4,2 pmol/1, kemudian meningkat saat kelahiran plasenta (Kala III) menjadi $17 \mathrm{pmol} / \mathrm{l}$.

Fungsi oksitosin pada persalinan kala tiga adalah menyebabkan kontraksi rahim. Kegagalan rahim berkontraksi dapat mengancam hidup ibu, dan penting melakukan tindakan seperti pengontrolan manajemen aktif kala III yaitu pemberian oksitosin, peregangan tali pusat terkendali dan massase fundus uteri. Asal usul fluktuasi endogen oksitosin tidak dapat ditentukan dari studi ini, tetapi beberapa pengamatan menunjukkan bahwa kenaikan tersebut disebabkan oleh peningkatan pelepasan oksitosin dari ibu dan janin. Oksitosin janin dapat berkontribusi dan beredar pada ibu sehingga konsentrasi plasma oksitosin meningkat selama kala I dan II persalinan, namun pada kala III oksitosin akan dihasilkan oleh tubuh ibu sendiri karena terjadi pengurangan metabolisme secara tiba-tiba akibat pelepasan plasenta, sehingga hipotalamus terstimulasi merangsang hormon oksiosin kemudian dialirkan melalui hipofisis posterior, kemudian menstimulasi jalan lahir selama persalinan. Kesimpulannya, $40 \%$ dari wanita yang tidak menerima pemberian oksitosin, konsentrasi plasma oksitosin endogen meningkat. Kenaikan ini mirip dengan yang telah diberikan oksitosin sintetik secara intramuskular. Sampai sekarang kita tidak bisa memprediksi kenaikan kadar oksitosin dapat terjadi secara alami ; Oleh karena itu, dengan asumsi bahwa kenaikan kadar oksitosin penting dalam persalinan normal, peneliti sarankan untuk memberikan oksitosin sintetik secara rutin untuk mencegah terjadinya perdarahan dan kejadian abnormal pada persalinan kala III (Thornton, et al., 2004).

\section{METODE PENELITIAN}

Penelitian ini dilakukan dengan cara observasional dan menggunakan pendekatan cross sectional. Penelitan ini dilakukan di Kota Padang dan Pariaman, Penelitian ini dilakukan selama 6 bulan. Populasi pada penelitian ini adalah seluruh ibu melahirkan normal yang memenuhi kriteria inklusi. Pengambilan sampel pada penelitian ini menggunakan prosedur non random sampling dan cara pengambilan sampel dengan accidental sampling. Kriteria inklusi dari sampel yang diambil adalah sebagai berikut :Ibu bersalin normal, Ibu dengan persalinan pervaginam, Tidak ada dilakukan induksi persalinan, Laserasi jalan lahir sudah di atasi dengan baik, Kehamilan tunggal,Tidak hidramnion, Kala II normal, Tidak ada penyakit sistemik, mis : Preeklampsia, Diabetes Melitus.

Kriteria eksklusi dari sampel yang diambil adalah sebagai berikut : Atonia uteri, Ruptura uteri. Data yang didapat dalam penelitian ini berasal dari data primer yang diperoleh dari observasi di BPM kota Padang dan Pariaman. Pengolahan data dilakukan uji statistik dengan menggunakan uji korelasi dan regresi dengan tingkat kepercayaan $95 \%$ dimana $\mathrm{P}<0,05$ yang artinya hubungan variabel independen dan variabel dependen bermakna. Data di olah secara komputerisasi.

Pengukuran waktu lama kala III akan dicatat dimulai setelah bayi lahir dan untuk menilai jumlah perdarahan kala IV peneliti melakukan penimbangan underpad kemudian dianalisa dengan rumus volume $(\mathrm{ml})=$ berat $/$ massa jenis darah $(1,056)$. Pengumpulan data kadar oksitosin untuk pengambilan darah peneliti dibantu oleh petugas laboratorium. Pemeriksaan kadar oksitosin dengan Human Oxytocin Elisa Kit kemudian diolah di Laboratorium Biomedik Fakultas Kedokteran Unand.

Variabel independen penelitian ini adalah kadar oksitosin dengan defenisi operasional hormon yang dihasilkan oleh hipotalamus yang berfungsi untuk merangsang kontraksi uterus dan mempercepat pelepasan plasenta. Pengukuran hormon oksitosin menggunakan Human Oxytocin Elisa Kit.

Variabel antara penelitian ini adalah Lama kala III persalinan dengan defenisi operasional segera setelah kelahiran bayi dan berakhir dengan kelahiran plasenta dan selaput ketuban. Cara ukur dengan melakukan pengamatan dan dilakukan pencatatan.

Variabel dependen penelitian ini adalah jumlah perdarahan postpartum dengan defenisi operasional Jumlah darah ibu yang keluar setelah melahirkan yaitu setelah plasenta lahir sampai 2 jam postpartum. Jumlah perdarahan kala IVdihitung dengan menimbang darah yang ditampung menggunakan underpad pada 2 jam postpartum. Hasil yang didapat kemudian diubah kedalam satuan volume (ml) dengan rumus : Volume=Berat/Massa Jenis. Dimana massa jenis darah adalah 1,056 .

\section{HASIL PENELITIAN}

Tabel 1. Rata-rata kadar hormon oksitosin

\begin{tabular}{c|c|c}
\hline Variabel & Mean \pm SD & $\begin{array}{c}\text { Minimal }- \\
\text { Maksimal }\end{array}$ \\
\hline Kadar & $50,41 \pm 2,07$ & $15,94-79,90$ \\
\hline
\end{tabular}




\begin{tabular}{|c|c|c|}
\hline $\begin{array}{l}\text { hormon } \\
\text { oksitosin }\end{array}$ & $\mathrm{pg} / \mathrm{ml}$ & $\mathrm{pg} / \mathrm{ml}$ \\
\hline
\end{tabular}

Pada tabel 1 dapat dilihat Kadar oksitosin minimal pada ibu persalinan kala III sebesar 15.94 $\mathrm{pg} / \mathrm{ml}$ dan kadar oksitosin maksimal sebesar 79.90 $\mathrm{pg} / \mathrm{ml}$, dengan rata-rata kadar oksitosin ibu 2 jam postpartum adalah $50.41 \mathrm{pg} / \mathrm{ml}$.

Tabel 2. Rata-rata Lama Kala III Ibu Bersalin Normal

\begin{tabular}{c|c|c}
\hline Variabel & Mean \pm SD & $\begin{array}{c}\text { Minimal }- \\
\text { Maksimal }\end{array}$ \\
\hline $\begin{array}{c}\text { Lama kala } \\
\text { III }\end{array}$ & $\begin{array}{c}5,7 \text { menit } \pm \\
1,89 \text { menit }\end{array}$ & 2 menit -9 menit \\
\hline
\end{tabular}

Berdasarkan tabel 2. dapat dilihat bahwa dari 30 responden didapatkan rata - rata lama kala III persalinan 5,7 menit dengan waktu minimal 2 menit dan waktu maksimal 9 menit.

Tabel 3. Rata-rata Jumlah Perdarahan Postpartum

\begin{tabular}{c|c|c}
\hline Variabel & Mean \pm SD & $\begin{array}{c}\text { Minimal - } \\
\text { Maksimal }\end{array}$ \\
\hline $\begin{array}{c}\text { Jumlah } \\
\text { perdarahan }\end{array}$ & $\begin{array}{c}157,15 \pm \\
76,51 \mathrm{ml}\end{array}$ & $\begin{array}{c}95,55-509,88 \\
\mathrm{ml}\end{array}$ \\
\hline
\end{tabular}

Pada tabel 3 dapat dilihat dari 30 responden rata rata jumlah perdarahan $157,15 \mathrm{ml}$ dengan jumlah perdarahan minimal 95,55 $\mathrm{ml}$ dan jumlah perdarahan maksimal 509,88 ml.

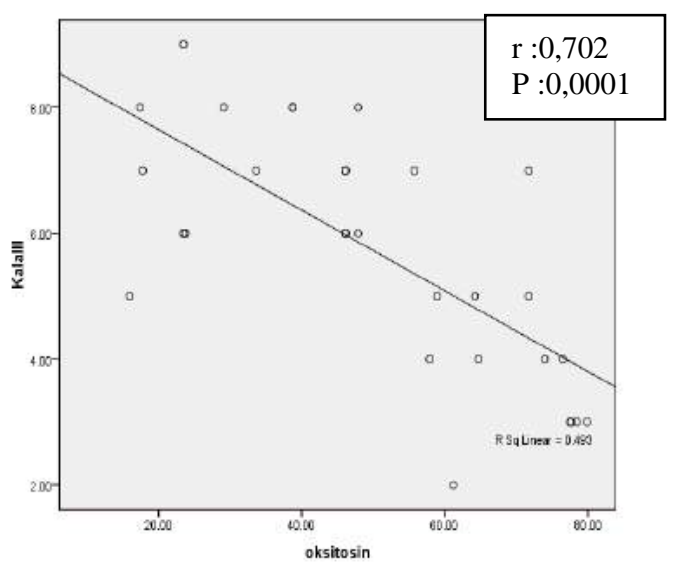

Gambar 1. Hubungan kadar Hormon Oksitosin terhadap lama kala III persalinan

Berdasarkan gambar 1. Hasil uji korelasi didapatkan hubungan kadar oksitosin terhadap lama kala III persalinan menunjukkan hubungan kuat $(\mathrm{r}=0,702)$. Hubungan dua variabel menunjukkan linear negatif artinya semakin tinggi kadar oksitosin maka semakin sedikit waktu lama kala III (melahirkan plasenta). Hasil uji statistik didapatkan ada pengaruh kadar oksitosin terhadap lama kala III persalinan $(\mathrm{p}<0,05)$.

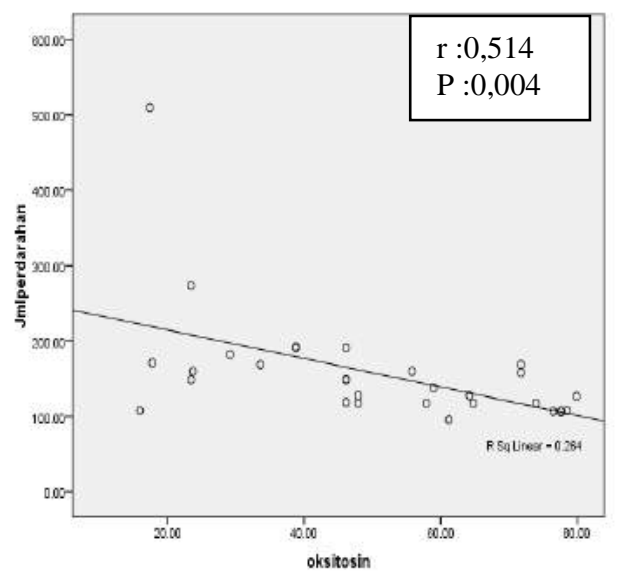

Gambar 2. Hubungan kadar hormon oksitosin terhadap jumlah perdarahan postpartum

Berdasarkan gambar 2. Hasil uji korelasi didapatkan hubungan kadar oksitosin terhadap jumlah perdarahan ibu 2 jam postpartum menunjukkan hubungan sedang $(\mathrm{r}=0,514)$. Hubungan dua variabel menunjukkan linear negatif artinya semakin tinggi kadar oksitosin maka semakin sedikit jumlah perdarahan pada ibu 2 jam postpartum. Hasil uji statistik didapatkan ada pengaruh kadar oksitosin terhadap jumlah perdarahan pada ibu 2 jam postpartum $(\mathrm{p}<0,05)$.

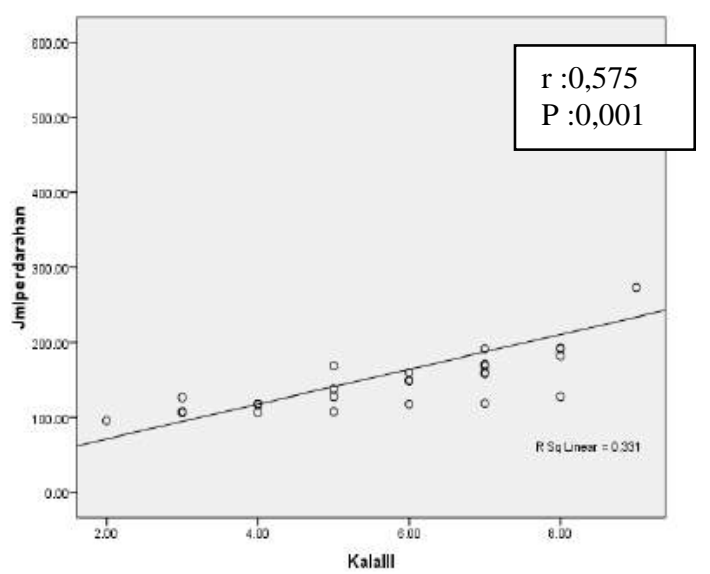

Gambar 3. Hubungan Lama Kala III dengan jumlah perdarahan postpartum

Berdasarkan gambar 3. didapatkan arah hubungan positif artinya semakin lama kala III maka akan semakin banyak jumlah perdarahan. nilai koefesien korelasi di dapatkan 0,575 yang artinya nilai korelasi hubungan variabel termasuk kategori sedang. Dari hasil uji statistik dengan regresi dan 
korelasi diperoleh nilai $P$-Value $\leq 0,05$, menunjukkan bahwa ada hubungan yang bermakna antara lama kala III dengan jumlah perdarahan postpartum.

\section{PEMBAHASAN}

\section{Rata-rata kadar Hormon Oksitosin}

Berdasarkan tabel 1 dapat dilihat Kadar oksitosin minimal pada ibu persalinan kala III sebesar 15.94 $\mathrm{pg} / \mathrm{ml}$ dan kadar oksitosin maksimal sebesar 79.90 $\mathrm{pg} / \mathrm{ml}$, dengan rata-rata kadar oksitosin ibu 2 jam postpartum adalah $50.41 \mathrm{pg} / \mathrm{ml}$.

Menurut penelitian Thornton menjelaskan bahwa 10 wanita yang diberikan oksitosin pada saat kelahiran plasenta menunjukkan peningkatan konsentrasi plasma oksitosin. Kadar oksitosin pada saat pengeluaran janin (Kala II) adalah sebesar 3,9 pmol/l kemudian meningkat pada saat kelahiran plasenta (Kala III) menjadi 23 pmol/1 setelah pemberian oksitosin. Peneliti juga menjelaskan bahwa dari 15 wanita yang tidak diberikan oksitosin, 9 orang memiliki waktu kelahiran plasenta yang normal dan 4 orang lagi tidak, namun plasenta dapat lahir walau dengan waktu yang lebih lama dan 2 orang yang mengalami perdarahan postpartum akibat manual plasenta. Plasma oksitosin meningkat pada saat Kala II dengan kadar oksitosin sebesar 4,2 pmol/1, kemudian meningkat saat kelahiran plasenta menjadi 17 pmol/l (Thornton, et al., 2004).

Fungsi oksitosin pada persalinan kala tiga adalah menyebabkan kontraksi rahim. Asal usul fluktuasi endogenoksitosin tidak dapat ditentukan dari studi ini, tetapi beberapa pengamatan menunjukkan bahwa kenaikan tersebut disebabkan oleh peningkatan pelepasan oksitosin dari ibu dan janin.Oksitosin janin dapat berkontribusi dan beredar pada ibu sehingga konsentrasi plasma oksitosin meningkat selama kala I dan II persalinan, namun pada kala III oksitosin akan dihasilkan oleh tubuh ibu sendiri karena terjadi pengurangan metabolisme secara tiba-tiba akibat pelepasan plasenta, sehingga hipotalamus terstimulasi merangsang hormon oksiosin kemudian dialirkan melaluihipofisis posterior, kemudian menstimulasi jalan lahir selama persalinan (Thornton, et al., 2004).

Oksitosin menginduksi otot polos miometrium uteri pada persalinan.Pemicu sintesis reseptor oksitosin dapat berupa peningkatan rasio estrogen terhadap progesteron seiring berkurangnya konsentrasi hormon progesteron selama persalinan. Oksitosin dilepaskan dari hipofisis posterior selama persalinan akibat rangsangan dilatasi serviks yang mengirimkan serat aferen ke sistem saraf pusat sehingga menyebabkan kelenjer hipofisis posterior meningkatkan sekresi oksitosinnya (Greenstein, 2010)

\section{Rata-rata Lama Kala III}

Berdasarkan tabel 2. dapat dilihat bahwa dari 30 responden didapatkan rata - rata lama kala III persalinan 5,7 menit dengan waktu minimal 2 menit dan waktu maksimal 9 menit.

Menurut penelitian yang dilakukan oleh Yulianti dan Supartini tahun 2011 sebanyak 74 bidan yang melakukan manjamen aktif kala III rata - rata waktu kelahiran plasenta 14,3 menit, hasil uji analisa menunjukkan bahwa manajemen aktif kala III dapat mempersingkat waktu lama kala III. ${ }^{6}$ Kala III persalinan umumnya berlangsung rata-rata antara 5 10 menit. Akan tetapi, kisaran normal kala III sampai 30 menit. Resiko perdarahan akan meningkat apabila kala III lebih lama dari 30 menit, terutama $30-60$ menit. ${ }^{7}$ Durasi dalam kala III persalinan sangat penting karena prevalensi perdarahan postpartum meningkat karena kala III yang lama. Tidak ada teori yang jelas tentang pengertian lama kala III. Menurut teori rata -rata lama kala III yaitu 5 - 6 menit, 90\% orang berpendapat lama kala III dalam waktu 15 menit dan $97 \%$ berpendapat lama kala III 30 menit. $^{8}$ Menurut asumsi peneliti lamanya kala III dapat beresiko terjadinya perdarahan postpartum. Untuk itu manajemen aktif kala III dapat dilakukan untuk mempersingkat waktu lamanya kala III (Yulianti, $\mathrm{dkk}, 2012$ )

\section{Rata-rata Jumlah Perdarahan Postpartum}

Berdasarkan tabel 3 dapat dilihat dari 30 responden rata - rata jumlah perdarahan $157,15 \mathrm{ml}$ dengan jumlah perdarahan minimal 95,55 $\mathrm{ml}$ dan jumlah perdarahan maksimal 509,88 ml.

Hasil dari data penelitian Stanton rata-rata jumlah perdarahan setelah plasenta lahir diberikan injeksi oksitosin adalah sebesar $185.5 \mathrm{ml}$ dan rata-rata jumlah perdarahan setelah plasenta lahir tanpa diberikan injeksi oksitosin $229.5 \mathrm{ml}$ (Stanton, et al., 2013).

Hormon oksitosin akan memicu kontraksi otot polos pada uterus sehingga akan terjadi involusi uterus dan mencegah terjadinya perdarahan.Oksitosin merupakan suatu hormon yang dapat memperbanyak masuknya ion kalsium kedalam intrasel.Keluarnya hormon oksitosin akan memperkuat ikatan aktin dan myosin sehingga kontraksi uterus semakin kuat dan proses involusi uterus semakin bagus.Hormon oksitosin yang dilepas dari kelenjar hipofisis memperkuat dan mengatur kontraksi uterus, mengompresi pembuluh darah dan membantu proses hemostasis.Kontraksi dan retraksi otot uterus akan mengurangi suplai darah ke uterus.Proses ini akan membantu mengurangi bekas luka implantasi plasenta serta mengurangi perdarahan (Bobak, 2005).

Perdarahan postpartum dalam arti luas mencakup semua perdarahan yang terjadi setelah kelahiran bayi; sebelum, selama, dan sesudah keluarnya plasenta. Perdarahan postpartum merupakan hilangnya darah lebih dari $500 \mathrm{ml}$ selama 24 jam pertama. Setelah 24 jam dinamakan perdarahan postpartum lanjut (late postpartum hemorrhage) (Bobak, 2005). Volume aliran darah yang melalui plasenta adalah 500-800 ml per menit. Pada saat plasenta terlepas, aliran ini harus 
dihentikan selama beberapa detik, jika tidak perdarahan yang serius akan terjadi. Tiga faktor yang mempengaruhi proses normal yang sangat penting dalam meminimalkan kehilangan darah pada saat persalinan. Faktor - faktor tersebut adalah retraksi serat - serat otot uterus oblik pada segmen atas uterus tempat pembuluh darah saling terjalin, adanya kontraksi uterus yang kuat setelah pemisahan, pencapaian hemostatis (Varney, 2008)

\section{Hubungan kadar Hormon Oksitosin terhadap lama kala III persalinan}

Berdasarkan gambar 1. Hasil uji korelasi didapatkan hubungan kadar oksitosin terhadap lama kala III persalinan menunjukkan hubungan kuat $(\mathrm{r}=0,702)$. Hubungan dua variabel menunjukkan linear negatif artinya semakin tinggi kadar oksitosin maka semakin sedikit waktu lama kala III (melahirkan plasenta). Hasil uji statistik didapatkan ada pengaruh kadar oksitosin terhadap lama kala III persalinan $(\mathrm{p}<0,05)$.

Menurut penelitian Thornton menjelaskan bahwa 10 wanita yang diberikan oksitosin pada saat kelahiran plasenta menunjukkan peningkatan konsentrasi plasma oksitosin. Kadar oksitosin pada saat pengeluaran janin (Kala II) adalah sebesar 3,9 pmol/l kemudian meningkat pada saat kelahiran plasenta menjadi $23 \mathrm{pmol} / \mathrm{l}$ setelah pemberian oksitosin.Peneliti juga menjelaskan bahwa dari 15 wanita yang tidak diberikan oksitosin, 9 orang memiliki waktu kelahiran plasenta yang normal dan 4 orang lagi tidak,namun plasenta dapat lahir walau dengan waktu yang lebih lama dan 2 orang yang mengalami perdarahan postpartum akibat manual plasenta. Plasma oksitosin meningkat setelah kelahiran bahu depan dengan kadar oksitosin sebesar 4,2 pmol/l,kemudian meningkat saat kelahiran plasenta menjadi 17 pmol/l (Thornton, et al., 2004).

Menurut penelitian yang dilakukan oleh Yulianti dan Supartini tahun 2011 sebanyak 74 bidan yang melakukan manjamen aktif kala III rata - rata waktu kelahiran plasenta 14,3 menit. Hasil uji analisa menunjukkan bahwa manajemen aktif kala III dapat mempersingkat waktu lama kala III. Kala III persalinan umumnya berlangsung rata-rata antara 5 10 menit. Akan tetapi, kisaran normal kala III sampai 30 menit. Resiko perdarahan akan meningkat apabila kala III lebih lama dari 30 menit, terutama $30-60$ menit. $^{7}$ Durasi dalam kala III persalinan sangat penting karena prevalensi perdarahan postpartum meningkat karena kala III yang lama.

Menurut penelitian yang dilakukan oleh Magann di American College of Obstetricians and Gynecologists tahun 2005 ditemukan 355 (5,1\%) ibu yang mengalami perdarahan postpartum dari 6.588 ibu bersalin pervaginam. Risiko perdarahan postpartum signifikan pada 10 menit. Pelepasan plasenta lebih lama akan menyebabkan perdarahan postpartum sehingga itu yang dikhawatirkan oleh tenaga kesehatan. Sewaktu suatu bagian plasenta (satu atau lebih lobus) tertinggal, maka uterus tidak dapat berkontraksi secara efektif dan keadaan ini dapat menimbulkan perdarahan. Gejala dan tanda yang bisa ditemui adalah perdarahan segera, uterus berkontraksi tetapi tinggi fundus tidak berkurang. Sebab plasenta belum lahir, bisa oleh karena plasenta belum lepas dari dinding uterus dan plasenta sudah lepas akan tetapi belum dilahirkan.

\section{Hubungan kadar hormon oksitosin terhadap jumlah perdarahan postpartum}

Berdasarkan gambar 2. Hasil uji korelasi didapatkan hubungan kadar oksitosin terhadap jumlah perdarahan ibu 2 jam postpartum menunjukkan hubungan sedang $(\mathrm{r}=0,514)$. Hubungan dua variabel menunjukkan linear negatif artinya semakin tinggi kadar oksitosin maka semakin sedikit jumlah perdarahan pada ibu 2 jam postpartum. Hasil uji statistik didapatkan ada pengaruh kadar oksitosin terhadap jumlah perdarahan pada ibu 2 jam postpartum $(\mathrm{p}<0,05)$.

Hasil dari data penelitian Stanton rata-rata jumlah perdarahan setelah plasenta lahir diberikan injeksi oksitosin adalah sebesar $185.5 \mathrm{ml}$ dan rata-rata jumlah perdarahan setelah plasenta lahir tanpa diberikan injeksi oksitosin $229.5 \mathrm{ml}$ (Stanton, et al., 2013).

Menurut penelitian Thornton (2004) menjelaskan bahwa 10 wanita yang diberikan oksitosin pada saat kelahiran plasenta menunjukkan peningkatan konsentrasi plasma oksitosin. Kadar oksitosin pada saat pengeluaran janin (Kala II) adalah sebesar 3,9 pmol/l kemudian meningkat pada saat kelahiran plasenta menjadi $23 \mathrm{pmol} / \mathrm{l}$ setelah pemberian oksitosin. Peneliti juga menjelaskan bahwa dari 15 wanita yang tidak diberikan oksitosin, 9 orang memiliki waktu kelahiran plasenta yang normal dan 4 orang lagi tidak, namun plasenta dapat lahir walau dengan waktu yang lebih lama dan 2 orang yang mengalami perdarahan postpartum akibat manual plasenta. Plasma oksitosin meningkat setelah kelahiran bahu depan dengan kadar oksitosin sebesar 4,2 pmol/1, kemudian meningkat saat kelahiran plasenta menjadi $17 \mathrm{pmol} / \mathrm{l}$.

Oksitosin menginduksi otot polos miometrium uteri pada persalinan. Pemicu sintesis reseptor oksitosin dapat berupa peningkatan rasio estrogen terhadap progesteron seiring berkurangnya konsetrasi hormon progesteron selama persalinan. Oksitosin dilepaskan dari hipofisis posterior selama persalinan akibat rangsangan dilatasi serviks yang mengirimkan serat aferen ke sistem saraf pusat sehingga menyebabkan kelenjer hipofisis posterior meningkatkan sekresi oksitosinnya (Bobak 2005).

Hormon oksitosin akan memicu kontraksi otot polos pada uterus sehingga akan terjadi involusi uterus dan mencegah terjadinya perdarahan. Oksitosin merupakan suatu hormon yang dapat memperbanyak masuknya ion kalsium kedalam intrasel. Keluarnya hormon oksitosin akan 
memperkuat ikatan aktin dan myosin sehingga kontraksi uterus semakin kuat dan proses involusi uterus semakin bagus.Hormon oksitosin yang dilepas dari kelenjar hipofisis memperkuat dan mengatur kontraksi uterus,mengompresi pembuluh darah dan membantu proses hemostasis.Kontraksi dan retraksi otot uterus akan mengurangi suplai darah ke uterus.Proses ini akan membantu mengurangi bekas luka implantasi plasenta serta mengurangi perdarahan (Bobak, 2005).

Menurut asumsi peneliti kadar oksitosin akan meningkat setelah kelahiran bayi, dimana ibu merasa bahagia melihat kelahiran bayinya. Sehingga produksi oksitosin dapat meningkat dan dapat mengurangi jumlah perdarahan postpartum. Pada penelitian ini sebagian ibu bersalin mengalami laserasi, hal ini menyebabkan rasa nyeri dan rasa cemas terhadap luka laserasi. Sehingga nyeri luka laserasi dapat menjadi salah satu penghambat pengeluaran hormon oksitosin. Ibu yang mempunyai tingkat nyeri yang tinggi dapat memblokade reflex pengeluaran hormon oksitosin karena adanya pelepasan hormon cortisol dan adrenalin

\section{Hubungan Lama Kala III dengan jumlah perdarahan postpartum}

Berdasarkan gambar 3. didapatkan arah hubungan positif artinya semakin lama kala III maka akan semakin banyak jumlah perdarahan. nilai koefesien korelasi di dapatkan 0,575 yang artinya nilai korelasi hubungan variabel termasuk kategori sedang. Dari hasil uji statistik dengan regresi dan korelasi diperoleh nilai $P$-Value $\leq 0,05$, menunjukkan bahwa ada hubungan yang bermakna antara lama kala III dengan jumlah perdarahan postpartum.

Hasil penelitian ini sama dengan penelitian yang dilakukan oleh Magann (2005) di American College of Obstetricians and Gynecologists tahun 2005 ditemukan $355(5,1 \%)$ ibu yang mengalami perdarahan postpartum dari 6.588 ibu bersalin pervaginam. Risiko perdarahan postpartum signifikan pada 10 menit. Pelepasan plasenta lebih lama akan menyebabkan perdarahan postpartum sehingga itu yang dikhawatirkan oleh tenaga kesehatan. Sewaktu suatu bagian plasenta (satu atau lebih lobus) tertinggal, maka uterus tidak dapat berkontraksi secara efektif dan keadaan ini dapat menimbulkan perdarahan. Gejala dan tanda yang bisa ditemui adalah perdarahan segera, uterus berkontraksi tetapi tinggi fundus tidak berkurang. Sebab plasenta belum lahir, bisa oleh karena plasenta belum lepas dari dinding uterus dan plasenta sudah lepas akan tetapi belum dilahirkan. Apabila plasenta belum lahir sama sekali, tidak terjadi perdarahan, jika lepas sebagian terjadi perdarahan yang merupakan indikasi untuk mengeluarkannya. Plasenta yang sudah lepas dari dinding uterus akan tetapi belum keluar, disebabkan tidak adanya usaha untuk melahirkan, atau salah penanganan kala tiga, sehingga terjadi lingkaran konstriksi pada bagian bawah uterus yang menghalangi keluarnya plasenta. ${ }^{7}$

\section{KESIMPULAN}

Terdapat hubungan kadar hormon oksitosin terhadap lama kala III, semakin tinggi kadar hormon oksitosin maka semakin sedikit waktu kala III persalinan.

Terdapat hubungan kadar hormon oksitosin terhadap jumlah perdarahan ibu postpartum, semakin tinggi kadar hormone oksitosin maka semakin sedikit jumlah perdarahan postpartum.

Terdapat hubungan lama kala III dengan jumlah perdarahan ibu postpartum, semakin sedikit waktu kala III persalinan maka semakin sedikit jumlah perdarahan postpartum.

\section{DAFTAR PUSTAKA}

1. Bobak, Lowdermilk, dan Jensen.Perdarahan Pascapartum Dalam Buku Ajar Keperawatan Maternitas (Edisi 4),Alih Bahasa Maria A Wijayanti. Peter I.Anugerah.Jakarta. EGC.2005

2. Greenstein B, Diana W.Hormon Oksitosin.Alih Bahasa At a Glance Sistem Endokrin edisi kedua. Jakarta.Erlangga.2010

3. Magann EF, Evans S, Chauhan SP, Lanneau G, Fisk AD, Morrison JC, The Length of The Third Stage of Labor and The Risk of Postpartum Hemorrhage. 2005

4. Norma D, N, dan Dwi S, M, Asuhan Kebidanan Patologi. Yogyakarta : Nuha Medika, 2013

5. Prawirohardjo S.Perdarahan Pascapersalinan.Ilmu Kebidanan. Jakarta: Yayasan Bina Pustaka Sarwono Prawirohardjo.2010.

6. Stanton CK.,Samuel N,Luke Cmu.Effect on Postpartum Hemorrhage of Prophylactic Oxytocin (10 IU) by Injection by Community Health Officers in Ghana.A CommunityBased,Cluster-Randomized Trial. Australia. The Journal University of Adelaide. 2013

7. Survey Demografi Kesehatan Indonesia.BPSBKKBN-KemenKes RI-Measure DHS.ICF International:2012.

8. Thornton S, Davison JM, Baylis PH.Plasma Oxytocin During Third Stage of Labour.Comparison of Natural and Active Management. Newcastle. Department of Obstetrics and Gynaecology Journal. 2004

9. Varney, H, dkk, Buku Ajar Asuhan Kebidanan. Jakarta : EGC, 2008

10. Yulianti, dkk, Hubungan Penerapan Standard Operating Procedures (Sop) Manajemen Aktif Kala III Dengan Lamanya Kelahiran Plasenta. Skripsi : Risbinakes Poltekkes Bandung, 2012 